\title{
Introduction Part II Colonial Hegemony, Arab Virtu and the Philosophy of History: Excavating, Exhibiting and Cultural Diplomacy in the Palestine Mandate
}

\author{
Philippe Bourmand
}

In Between Past and Future, Hannah Arendt explores the philosophical implications of the way the understanding of history changed in the modern age. In confronting the belligerent masses of the past and the future, historical actors are crushed less by the opposed social forces of tradition and progress in the Gramscian sense, than by the weight of the consciousness of history over all human actions. ${ }^{1}$ All actions happen in a process, and all an individual can do is to hone their skills at grasping historical processes and to find allies in tradition and modernity in order to act decisively. Virtì, the Machiavellian quality of the Prince able to play among forces that overwhelm him and seize the moment, is an early manifestation of this modern consciousness of history: the alliance of an understanding of the crucial and yet constantly forgotten character of foundational moments that orientate history, and of a capacity to show one's will in the right moment in the present, so as to make a political difference. ${ }^{2}$

\footnotetext{
${ }^{1}$ Hannah Arendt, La Crise de la culture, coll. Folio Essais (Paris: Gallimard, 2018), 16.

${ }^{2}$ Ibid., 178-185.
}

P. Bourmaud $(\triangle)$

Université Jean Moulin, Lyon 3, Lyon, France

e-mail: philippe.bourmaud@univ-lyon3.fr 
My goal here is obviously not to advertise virtì as useful for the social sciences, when a forest of robust methods and concepts exists to account for individual choices. But the notion captures well the feelings of individuals confronted with experiences of profound, at once auspicious and ominous, and thus foundational political changes, and why a sense of history matters under such circumstances. There was a lot, for instance, for the denizens of Palestine under the Mandate, that required virtì, adaptation and creativity in order to have a say in the shaping of the new political realities. Newcomers, adventurers, prophets of salvation and doom were many, as were men and women with historical expertise, projects and an axe to grind. Knowing one's way in society and understanding history were assets wherever the past and the modern, which both were part and parcel of the goals of colonial rule, were on display.

It could be argued that virtì had several components and quasi-synonyms. As mutual stereotypes of the Jewish and Arab national communities took form, collective images may not have been absent from cultural debates. Arab academics, intellectuals and artists may have recoiled at behaviours that would have been identified as British imperial arrogance on the one hand, or chutzpah on the part of Zionists on the other. In her chapter, Mathilde Sigalas analyses the collaboration and competition between British, French and American archaeological institutions during the Mandate. What she shows could again be called virtù: the Americans, seen as newcomers in the field of Palestinian archaeology, were actively constructing a business-like and efficient collective image, even as they worked to dig and display the Palestinian past. Older actors, seen as increasingly less relevant, could also play with their self-image in a strategic and opportunistic fashion: Barbara Haider-Wilson's piece on the history of Austrian humanitarian and cultural diplomacy in Palestine highlights how Republican Austria banked on the good reputation left by the Austrian military presence in Palestine during World War I. Selfassertive behaviours were commonly frowned upon in Arab locales. But as Sherene Seikaly makes clear in the case of modernist Arab capitalists, ${ }^{3}$ there was no shortage of Arab individuals ready to seize the circumstances offered by the Mandate.

Among Arabs, those who were able to seize opportunities in the cultural realm did not come from just anywhere. Indeed, the initial interrogation of the editors of this volume on the fortunes of Arab Christians in the cultural arena-or their misfortune, perhaps, in being sidelined in most other aspects of policy-shows examples of virtì, and of its absence. Sarah Irving's chapter on two Arab Christians in the Department of Archaeology of the Government of Palestine presents two contrasted trajectories. Stephan Stephan stands out as a well-connected, self-staging successful figure, savvy

\footnotetext{
${ }^{3}$ Sherene Seikaly, Men of Capital: Scarcity and Economy in Mandate Palestine (Stanford: Stanford University Press, 2016), 23-52.
} 
about the mindset of his British superiors and about when to make his nationalistic research agenda explicit, and when not. Yet the career of his colleague Na'im Makhouly, presenting similar sociological and educational features, appears much less successful, especially when we consider the shortage of trained archaeological staff in Palestine in those years. How can we make sense of the contrast? Irving suggests that geographical origins-in Stephan Stephan, his ties to the centre of the Mandate and of Palestine's cultural life, Jerusalem-matter more than denominational belonging and the educational opportunities it gave Arab Christians. But further research might also tell us about the qualities nurtured through education, and in particular the role of pedagogy: what was special about the teaching at schools such as the Syrian Orphanage, near Jerusalem, attended by many prominent figures, Stephan included? Was the pedagogy so different in Makhouly's village of Kufr Yasif, also known for its numerous intellectuals? What made a difference-individual psychology, pedagogy, the whole networks (professional, geographic, religious, or else) around the individual, or all of these combined?

Showing a daring sense of opportunity was rewarded by the Mandate system. In the cultural arena, opportunities owed not only to the pervasiveness of the Bible in Britain's psyche, but also to the theatrical nature of the Mandate, whose results were under yearly examination by the League of Nations, and afterwards by many public and private organisations. The competition between Arabs and Jews in Palestine meant not only that British rule in Palestine was staged for representation in Geneva, but that all aspects of collective action tended to be theatricalised; and this was no less true of archaeology, which the Mandate charter made it incumbent upon the British authorities to promote. Museums, as sites of representation of the past, and international exhibitions, devoted to anticipating the future as much as to marketing the present, were of more direct diplomatic importance on the international stage than the kind of alternative diplomatic channel that is suggested by the expression "cultural diplomacy".

What seemed lost in the new circumstances of the Mandate, though, was the past as tradition. The simultaneous political redefinition of the country in Biblical terms, "from Dan to Beersheba", as claimed by British diplomats during the Paris peace conference, ${ }^{4}$ and the public dismissal of the Ottoman past by Britain and Arab nationalists alike,${ }^{5}$ meant that the past was cleanly cut from the present. Connection to the past could only be restored through operations of re-establishing and exhibiting historical continuityby Western-trained expertise. The collaborative efforts of archaeologists,

\footnotetext{
${ }^{4}$ Gideon Biger, The Boundaries of Modern Palestine, 1840-1947 (London: Routledge, 2004), 69-70.

${ }^{5}$ The dismissal was neither complete nor immediate, however, as the Ottoman order compared favourably to the new colonial reality in the eyes of Ottoman-turned-Arab leaders. See Michael Provence, The Last Ottoman Generation and the Making of the Modern Middle East (Cambridge: Cambridge University Press, 2017).
} 
highlighted by Mathilde Sigalas in her chapter, anthropologists and museum curators, was the cultural translation of the foundation of an old-new political construct. Mandatory Palestine was born of a promise to found a new reality - the Jewish National Home under the aegis of the British Empire-in a new system - the Mandate - on a claim to legitimacy based on anteriorityJewish Palestine and the crusades-and imported traditions-Jewish diasporic cultures and British imperial government. Much like Marx's remark that the French Revolution was cloaked in Roman clothes, ${ }^{6}$ Mandatory Palestine was supposed to be created in Biblical image.

But what of the future, then? Where was "the sacred trust of civilization" known as the Mandate taking Palestine? Was it also to be, in René Char's words, "an inheritance without a will" - a creation from scratch? Far from it, as Palestine was already home to institutions of science, such as the British School of Archaeology and the Ecole Biblique et Archéologique Françaiseand design - in the case of the Bezalel School - that were waiting to reopen or expand. Yet, as Nisa Ari explains in her chapter, the work of fashioning and designing a new Palestine was initially understood by the colonial administration to be inspired by the spirit of the Mandate-i.e. the native population had to be brought to the conditions of the modern world by Western minds, following Western models.

Colonial notions soon encountered a self-assertive Arab reality. Very early on, Arab political leaders and intellectuals made it clear that they would have a say in the shaping of the new country. And in their eyes, the selective memory of the new rulers and their Western partners in expertise, dissected here by Mathilde Sigalas, as well as their disregard for the Islamic history of the country, contrasted by Sarah Irving with the interest of (Muslim and Christian) Arab archaeologists, was highly questionable. There was an Arab history to publicise, cultural projects and a sense of design that were part of Arab claims to sovereignty. Design and fashion were sites of self-assertion of Arab agency throughout the Mandate. By 1929, competing projects for an Arab national flag were floated in the Arabic press. ${ }^{7}$ The politics of dress intersected with inter-Arab class wars during the Arab Revolt of 1936-1939, when the suit-and-tarbush-wearing Arab bourgeoisie was briefly made to wear elements of traditional rural dress by the insurgents. ${ }^{8}$ From literature to design, to architecture, to music, all forms of cultural creation were discussed within the Arab community. A historiographical stress has been put on "the politics of popular culture". 9 But this is a reflection of the way Arabs, having

\footnotetext{
${ }^{6}$ Quoted in Arendt, La Crise de la culture, 183.

${ }^{7}$ Tamir Sorek, "The Orange and the Cross in the Crescent-Imagining Palestine in 1929," Nations and Nationalism 10, no. 3 (2004): 269-291.

${ }^{8}$ Ted Swedenburg, Memories of Revolt: The 1936-1939 Rebellion and the Palestinian National Past (Fayetteville: University of Arkansas Press, 2003), 32-33.

${ }^{9}$ Rebecca L. Stein and Ted Swedenburg, eds., Palestine, Israel, and the Politics of Popular Culture (Durham and London: Duke University Press, 2005).
} 
been cornered into supposedly inferior and iterative cultural forms (highlighted by Nisa Ari throughout her piece, and by Barbara Haider-Wilson in the evocation of the unusual interest shown by Austrian cultural diplomats for Arab artefacts), used cultural hierarchies to protest and subvert the colonial order. Yet this twist, which has to do with the economic hardships of the 1930s, should not hide the versatile, heritage- and creation-oriented cultural concerns displayed by Arabs.

Indeed, public debate among Mandatory Palestine's Arabs was full of interrogations about the referential past and future ideals on which they wanted to base their new polity. Some of these questions articulated the academic and the political: how to counter Zionist claims to anteriority, and yet to dismiss European images of an unchanging East at the same time? Should certain historical periods be used defensively, perhaps even weaponised against Zionist historical claims, should national history be used as a mobilising tool and therefore appeal to popular imagination within the Arab community, or should the whole and long history of the land be embraced? ${ }^{10}$ In any case, as Sarah Irving reminds us, the colonial endorsement of Biblical archaeology and the epistemological influence of exegetic literalism in that endeavour since the 1830s, now an historiographical commonplace, was immediately felt to be political and hegemonic in nature by Palestinian Arabs, and at their expense.

Other debates were axiological, but values blended with aesthetics and strategies of mobilisation: how to accommodate cultural "authenticity" and signifiers of modernity? How could Arabs define, preserve and represent heritage, how could they experiment with shapes and structures that could stand in the future on their own terms, when the British government controlled policy-making and funding, and the Zionist movement had already claimed a monopoly over modern forms and codified them with references to its own heritage? When the political, economic and scientific playing fields could not be described as on a level for Arabs and Zionists, should the former accept the game of intercommunal collaboration as junior partners? Or, as the decision to set up the Arab Fair of Jerusalem in Nisa Ari's chapter illustrates, should they resort to boycott and exclusive institutions? These questions structured cultural public debates among Arabs and beyond; they also attested to the undecided, foundational character of the era.

The newly hegemonic Biblical reading of history had effective marginalising effects for the Arab community, though, and denied it an autonomous course in history. In Ottoman times, Palestine and its inhabitants had been included in narratives that made history closer, and thus more relatable. Teleological Ottoman historiography stressed the inevitability of the Empire's reforms and, their violent enforcement notwithstanding, they made a bridge

\footnotetext{
${ }^{10}$ Salim Tamari, "Lepers, Lunatics, and Saints: The Nativist Ethnography of Tawfik Canaan and His Jerusalem Circle," in Mountain Against the Sea: Essays on Palestinian Society and Culture, ed. Salim Tamari (Berkeley: University of California Press, 2009), 93-112.
} 
between the more distant past, the present and beyond. Tarih Cevdet, the epitome of this historiographical trend, had been popularised in the Arab Levant by Ahmad Faris al-Shidyaq, a journalist and intellectual born in present-day Lebanon, in the 1870s. ${ }^{11}$ Even ancient archaeology was concerned by the endeavour to make history both Ottoman and local: the long-standing head of the Imperial Archaeological museum in Istanbul, Osman Hamdi Bey, did not limit himself, in his militant defence of Ottoman archaeological heritage, to the organisation of a central institution in Istanbul. He also supported projects aiming at the creation of other Müze- $i$ bumayun in archeologically significant locales, such as, from 1901 onwards, Jerusalem. ${ }^{12}$ The collapse of the Ottoman state undermined the position of Ottoman history and heritage as the past with which people could identify; but then, with the British and the Zionists co-opting the Biblical past as their own, what historical narrative could shore up national claims? And how to disprove a teleological idea, namely the mandatory claim that civilisation was on the side of the coloniser? How could Arabs dismiss the colonial articulation of the past and the future which relegated them to the status of case study for evolutionary anthropology and a function of illustration of Biblical times? Based on what historical references, with which academic and cultural tools, and through which networks or channels of public opinion, would they be able to counter a deeply rooted Western Biblical imagination which assigned them a passive historical role?

The past and the future were heavily contested notions, but as such they offered ample opportunities for various new actors to intervene: international organisations and American archaeologists, as illustrated by Mathilde Sigalas; Arab Christians with modern education and expertise, in Sarah Irving's paper; or artists and entrepreneurs, who feature in Nisa Ari's chapter.

Ironically enough, it could be said that the virtì of the men and women of the Mandate and the foundational character of the period were lost on later visitors: when Hannah Arendt visited the West Bank and Gaza in the aftermath of the war of June 1967, she read the landscapes she saw through the lens of development and of the most recent history, blaming Gamal Abd al-Nasser squarely for the state she found the Gaza Strip in and infamously suggesting he "be hung instantly". ${ }^{13}$ Much as no history of Gaza could make sense of its present without taking into account the forced migrations during and following the war of 1948, no analysis of heritage in Palestine/Israel today could skip over the aesthetic and policy choices that Arabs made during

${ }^{11}$ Juan R. Cole, Colonialism and Revolution in the Middle East: Social and Cultural Origins of Egypt's 'Urabi Movement (Cairo: American University in Cairo Press, 1999), 116.

${ }^{12}$ Beatrice St. Laurent and Himmet Taskomur, "The Imperial Museum of Antiquities in Jerusalem, 1890-1930: An Alternative Narrative," Jerusalem Quarterly 55 (Autumn 2013): 6-45.

${ }^{13}$ Quoted in Susie Linfield, The Lion's Den: Zionism and the Left from Hannah Arendt to Noam Chomsky (New Haven: Yale University Press, 2019), 77-78. 
the Mandate, under fluid circumstances, to select visions of the past and the future and articulate them into images of the newly carved territory.

\section{BIBLIOGRAPHY}

Arendt, Hannah. La Crise de la culture, coll. Folio Essais. Paris: Gallimard, 2018.

Biger, Gideon. The Boundaries of Modern Palestine, 1840-1947. London: Routledge, 2004.

Cole, Juan R. Colonialism and Revolution in the Middle East: Social and Cultural Origins of Egypt's 'Urabi Movement. Cairo: American University in Cairo Press, 1999.

Linfield, Susie. The Lion's Den: Zionism and the Left from Hannah Arendt to Noam Chomsky. New Haven: Yale University Press, 2019.

Provence, Michael. The Last Ottoman Generation and the Making of the Modern Middle East. Cambridge: Cambridge University Press, 2017.

Seikaly, Sherene. Men of Capital: Scarcity and Economy in Mandate Palestine. Stanford: Stanford University Press, 2016.

Sorek, Tamir. "The Orange and the Cross in the Crescent-Imagining Palestine in 1929." Nations and Nationalism 10, no. 3 (2004): 269-291.

St. Laurent, Beatrice and Himmet Taskomur. "The Imperial Museum of Antiquities in Jerusalem, 1890-1930: An Alternative Narrative." Jerusalem Quarterly 55 (Autumn 2013): 6-45.

Stein, Rebecca L. and Ted Swedenburg, eds. Palestine, Israel, and the Politics of Popular Culture. Durham and London: Duke University Press, 2005.

Swedenburg, Ted. Memories of Revolt: The 1936-1939 Rebellion and the Palestinian National Past. Fayetteville: University of Arkansas Press, 2003.

Tamari, Salim. "Lepers, Lunatics, and Saints: The Nativist Ethnography of Tawfik Canaanand His Jerusalem Circle." In Mountain Against the Sea: Essays on Palestinian Society and Culture, edited by Salim Tamari, 93-112. Berkeley: University of California Press, 2009.

Open Access This chapter is licensed under the terms of the Creative Commons Attribution 4.0 International License (http://creativecommons.org/licenses/ by $/ 4.0 /$ ), which permits use, sharing, adaptation, distribution and reproduction in any medium or format, as long as you give appropriate credit to the original author(s) and the source, provide a link to the Creative Commons license and indicate if changes were made.

The images or other third party material in this chapter are included in the chapter's Creative Commons license, unless indicated otherwise in a credit line to the material. If material is not included in the chapter's Creative Commons license and your intended use is not permitted by statutory regulation or exceeds the permitted use, you will need to obtain permission directly from the copyright holder.

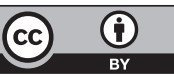

